\title{
From arginine methylation to ADMA: A novel mechanism with therapeutic potential in chronic lung diseases Dariusz Zakrzewicz ${ }^{1}$ and Oliver Eickelberg*2,3
}

Address: ${ }^{1}$ University of Giessen Lung Center, Department of Medicine II, Aulweg 123, 35392 Giessen, Germany, ${ }^{2}$ Comprehensive Pneumology Center, Munich, Germany and ${ }^{3}$ Institute of Lung Biology and Disease, Helmholtz Zentrum München, Munich/Neuherberg, Germany

Email: Dariusz Zakrzewicz - Dariusz.Zakrzewicz@uglc.de; Oliver Eickelberg* - oliver.eickelberg@helmholtz-muenchen.de

* Corresponding author

Published: 29 January 2009

BMC Pulmonary Medicine 2009, 9:5 doi:10.1 I86/147/-2466-9-5

This article is available from: http://www.biomedcentral.com/I47/-2466/9/5

(C) 2009 Zakrzewicz and Eickelberg; licensee BioMed Central Ltd.

This is an Open Access article distributed under the terms of the Creative Commons Attribution License (http://creativecommons.org/licenses/by/2.0), which permits unrestricted use, distribution, and reproduction in any medium, provided the original work is properly cited.
Received: 30 October 2008

Accepted: 29 January 2009

\begin{abstract}
Protein arginine methylation is a novel posttranslational modification regulating a diversity of cellular processes, including protein-protein interaction, signal transduction, or histone function. It has recently been shown to be dysregulated in chronic renal, vascular, and pulmonary diseases, and metabolic products originating from protein arginine methylation have been suggested to serve as biomarkers in cardiovascular and pulmonary diseases.

Protein arginine methylation is performed by a class of enzymes called protein arginine methyltransferases (PRMT), which specifically methylate protein-incorporated arginine residues to generate protein-incorporated monomethylarginine (MMA), symmetric dimethylarginine (SDMA), or asymmetric dimethylarginine (ADMA). Upon proteolytic cleavage of arginine-methylated proteins, free intracellular MMA, SDMA, or ADMA is generated, which, upon secretion into the extracellular space (including plasma), directly affects the methylarginine concentration in the plasma. Free methylarginines are cleared from the body by renal excretion or hepatic metabolism. In addition, MMA and ADMA, but not SDMA, can be degraded via a class of intracellular enzymes called dimethylarginine dimethylaminohydrolases (DDAH).

ADMA and MMA are endogenous inhibitors of nitric oxide synthases (NOS) and ADMA has been suggested to serve as a biomarker of endothelial dysfunction in cardiovascular diseases. This view has now been extended to the idea that, in addition to serum ADMA, the amount of free, as well as protein-incorporated, intracellular ADMA influences pulmonary cell function and determines the development of chronic lung diseases, including pulmonary arterial hypertension (PAH) or pulmonary fibrosis. This review will present and discuss the recent findings of dysregulated arginine methylation in chronic lung disease. We will highlight novel directions for future investigations evaluating the functional contribution of arginine methylation in lung homeostasis and disease with the outlook that modifying PRMT or DDAH activity presents a novel therapeutic option for the treatment of chronic lung disease.
\end{abstract}




\section{A brief introduction to protein arginine methylation}

During the last 40 years, arginine methylation has been extensively studied in prokaryotes and eukaryotes, revealing a pivotal role of this posttranslational modification in the regulation of a number of cellular processes. Protein arginine methylation is involved in the modulation of transcription, RNA metabolism, or protein-protein interaction, thereby controlling cellular differentiation, proliferation, survival, or apoptosis $[1,2]$.

The methylation of protein arginine residues is catalyzed by a family of intracellular enzymes termed protein arginine methyltransferases (PRMT) [2] (Figure 1). In mammalian cells, these enzymes have been classified into type I (PRMT1, 3, 4, 6, and 8) and type II PRMT (PRMT5, 7 , and FBXO11), depending on their specific catalytic activity. In addition, PRMT2 was identified as a methyltransferase most probably belonging to type I enzymes, but its methyltransferase activity has yet not been unequivocally characterized [2]. Both types of PRMT, however, catalyze the formation of mono-methylarginine (MMA) from L-arginine (L-Arg). In a second step, type I PRMT produce asymmetric dimethylarginine (ADMA), while type II PRMT form symmetric dimethylarginine (SDMA) [1,2]. After proteolytic degradation of methyl-

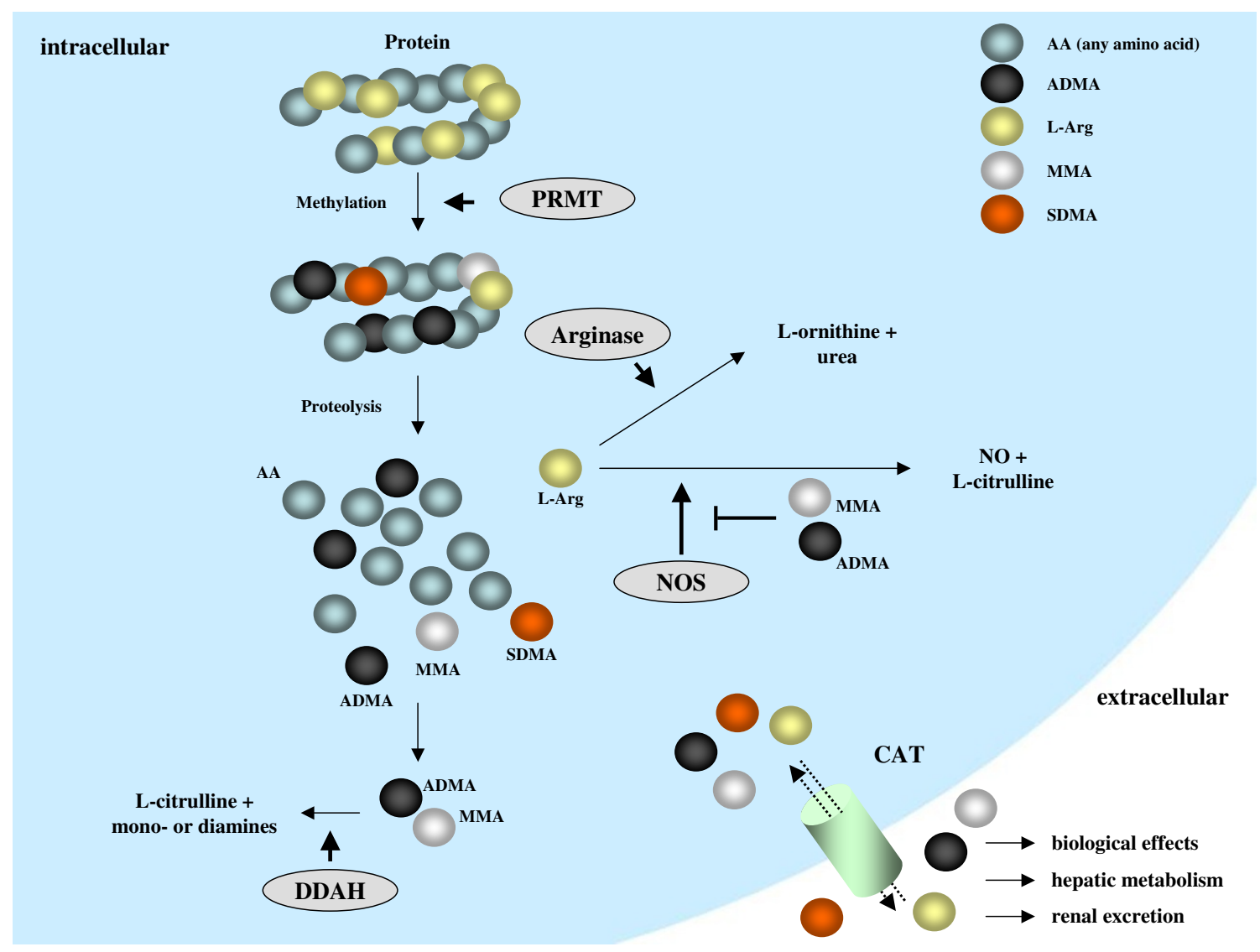

\section{Figure I}

Methylarginine metabolism. Protein arginine methylation is performed by a class of enzymes termed protein arginine methyltransferases (PRMT), which specifically methylate protein-incorporated L-arginine (L-Arg) residues to generate proteinincorporated monomethylarginine (L-MMA), asymmetric dimethylarginine (ADMA), or symmetric dimethylarginine (SDMA). Upon proteolytic cleavage of arginine-methylated proteins, free intracellular MMA, ADMA, or SDMA are generated. Free LArg can be metabolized by arginases to L-ornithine and urea, or by nitric oxide synthases (NOS) to NO and L-citrulline. Free methylarginines can also be released to the extracellular space by cationic amino acid transporters (CAT) to induce distinct biological effects, undergo hepatic metabolism, or renal excretion. MMA and ADMA, but not SDMA can be converted to L-citrulline and mono- or diamines by a class of intracellular enzymes called dimethylarginine dimethylaminohydrolases (DDAH). Most importantly, MMA and ADMA, but not SDMA, act as potent endogenous inhibitors of NOS enzymes. 
ated intracellular proteins, free MMA, SDMA, or ADMA can be released from cells (Figure 1). Thus, protein degradation represents the major source of free intracellular methylarginines, as there is currently no evidence that free L-Arg can be methylated [3,4]. In addition, intracellular proteolysis of methylated proteins also significantly contributes to interstitial and plasma ADMA levels, which are further controlled by degradation and cellular export/ import of methylarginines. Released ADMA can also be taken up by other cells via the cationic amino acid $\left(\mathrm{y}^{+}\right)$ transporters, which are widely expressed in mammalian cells [5](Figure 1).

Free methylarginines are cleared from the body by renal excretion and hepatic metabolism [3,4]. In addition, MMA and ADMA, but not SDMA, can be degraded to citrulline and mono- or dimethylamines, respectively, by dimethylarginine dimethylaminohydrolases (DDAH) [3]. To date, two DDAH isoforms have been cloned and characterized, termed DDAH1 and DDAH2 [3]. Alternatively, ADMA can also be converted to $\alpha$-keto valeric acid by alanine:glyoxylate aminotransferase 2 [6], although the influence of this pathway on total ADMA metabolism has not been extensively studied thus far. Of interest, the demethylation/clearance of methylarginines is restricted to free methylarginines, as a theoretically possible demethylation of protein-incorporated, methylated L-Arg residues in situ has yet not been demonstrated. It should be noted, however, that the conversion of protein-incorporated MMA to citrulline by peptidylarginine deiminase 4 was recently demonstrated, which prevented histone methylation by PRMT 1 and 4 [7,8]. This may influence protein methylation directly, as MMA deimination will decrease the amount of protein-incorporated MMA that is available for dimethylation by PRMT, but the relevance of protein deimination of protein-incorporated MMA by PAD enzymes has also been challenged lately $[9,10]$. Finally, free SDMA has been described to be catabolized in vivo when injected intraperitoneally into rats, although the enzymes involved have thus far not been identified [11].

ADMA has been detected in urine, plasma, cerebrospinal and bronchoalveolar lavage (BAL) fluids, and various types of tissues $[3,4,12,13]$. Specific methylation of protein-incorporated L-Arg residues was originally described in 1968 [14], but the key finding that ADMA is a potent inhibitor of all three nitric oxide synthase (NOS) isoforms (nNOS, iNOS, and eNOS), resulting in impaired NO production in vitro and in vivo, was only reported in 1992 by Vallance et al. [15]. NO is a well-known vasodilator that essentially controls a diverse range of pulmonary functions, such as macrophage activity, pulmonary artery vasodilation, or bronchoconstriction [16]. ADMA may therefore control pulmonary cell functions either via direct effects on gene expression and protein function, as recently shown in an elegant study [17], or via inhibition of NOS and subsequently altered NO generation. Furthermore, the lung generates a significant amount of ADMA itself, and as such may directly contribute to interstitial and plasma ADMA levels [18], further suggesting that dysregulated $\mathrm{ADMA}$ metabolism in the lung may trigger, initiate, or perpetuate chronic lung diseases, such as pulmonary arterial hypertension (PAH), idiopathic pulmonary fibrosis (IPF), asthma, or chronic obstructive pulmonary disease (COPD). In the following, we will outline the current evidence of dysregulated protein arginine methylation or ADMA levels in specific lung diseases.

\section{Arginine methylation in pulmonary arterial hypertension}

Pulmonary arterial hypertension (PAH) is a fatal syndrome characterized by an elevated blood pressure in the pulmonary circulation, due to increased resistance of pulmonary arterioles [19]. The pathophysiology of PAH includes endothelial dysfunction and pulmonary arterial smooth muscle cell (PASMC) hypertrophy and proliferation [20]. Elevated ADMA concentrations have been detected in the plasma of patients with idiopathic (I)PAH [21-23], chronic thromboembolic pulmonary hypertension (CTEPH) [24], or PAH related to sickle cell disease [25] or systemic sclerosis [26], suggesting a strong association of circulating methylarginine levels with $\mathrm{PAH}$ pathogenesis. A recent study by $\mathrm{Xu}$ et al., however, detected increased arginase activity in the serum of PAH patients, whereas serum ADMA levels did not differ between PAH patients and healthy individuals, suggesting that increased arginase activity was responsible for endothelial dysfunction observed in PAH [27]. This is of particular interest, as arginase directly metabolizes free LArg. Increased arginase activity as well as ADMA content was subsequently confirmed in pulmonary arterial endothelial cells in the rat model of monocrotalineinduced pulmonary hypertension [28].

The investigation of animal models of PAH, using e.g. chronic hypoxia or the pyrrolizidine alkaloid monocrotaline to induce PAH in piglets, mice, or rats, have largely detected increased plasma ADMA during the development of experimental PAH, but have thus far suggested different mechanisms responsible for this increase. While some groups have reported decreased DDAH1 expression along with increased ADMA levels $[28,29]$, others have detected decreased DDAH2 in this condition $[22,30]$. Most importantly, the analysis of lung tissues obtained from IPAH or control patients have demonstrated an impaired expression of DDAH2, but not DDAH1, in IPAH [22]. Furthermore, PRMT expression was found to be upregulated in mice exposed to chronic hypoxia, resulting in increased ADMA tissue levels and a decreased L-Arg/ 
ADMA ratio, thereby supporting an important role of PRMT-mediated ADMA generation in hypoxia-induced PAH [31].

In sum, disrupted methylarginine metabolism most likely impairs vascular homeostasis in $\mathrm{PAH}$, but it remains unclear, which DDAH or PRMT isoforms control ADMA tissue and plasma levels under pathological conditions. Further, the relative contributions of serum, interstitial, or pulmonary ADMA levels to $\mathrm{PAH}$ pathogenesis remain unclear, as comparative investigations are still lacking. Data obtained in transgenic mice with manipulation of DDAH expression have thus far supported a major role for DDAH1 in serum and tissue ADMA homeostasis. Forced overexpression of DDAH-1 in transgenic mice resulted a 2 -fold reduction in plasma ADMA levels and decreased blood pressure [32], while the loss of DDAH-1 activity by homologous recombination in mice led to accumulation of circulating ADMA and increased blood pressure [33]. In contrast, forced overexpression of DDAH2 led only to a $20 \%$ reduction in circulating ADMA, but no reduction in systemic blood pressure [34].

\section{Arginine methylation in pulmonary fibrosis}

Compared with the aforementioned available data on ADMA and vascular remodeling in PAH, much less is known about the role of methylated arginines in interstitial remodeling of the lung, e. g. in idiopathic pulmonary fibrosis (IPF). A growing body of evidence, however, suggests that arginine methylation and ADMA metabolism may be involved in the progression of IPF, a lethal disorder of major concern due to its unresolved pathogenesis and limited responsiveness to currently available therapies [35]. The hallmark lesions of IPF are fibroblast foci, which are sites featuring $\alpha$-smooth muscle actin ( $\alpha \mathrm{SMA})$ positive, activated (myo)fibroblasts that synthesize and deposit a collagen-rich extracellular matrix [36]. Fibroblast foci occur in subepithelial layers adjacent to areas of alveolar epithelial cell injury, suggesting that altered epithelial-mesenchymal crosstalk contributes to the pathobiology of IPF. Indeed, it is well accepted that repetitive alveolar epithelial cell injury and subsequent repair, in the presence or absence of local inflammation, represents a key pathogenic mechanism in IPF [35,36]. This leads to aberrant growth factor activation and perpetuation of fibrotic transformation. In addition to the well-described cytokines and growth factors interleukin- $4,-13,-21$, wingless, or transforming growth factor- $\beta$, components of the renin-angiotensin-aldosterone system including angiotensin II (ANGII) have recently been identified as important regulators of fibrosis [37,38].

Interestingly, ANGII infusions increased plasma ADMA levels and caused perivascular and interstitial renal fibrosis $[34,39]$. Overexpression of DDAH $1 / 2$ protected from
ANG II-induced ADMA increases and interstitial fibrosis $[34,39]$. These data suggest an delicate causal relationship between ANGII-ADMA and the development of perivascular and interstitial fibrosis, which has to be further explored in human IPF in future studies. Most importantly, direct infusion of ADMA resulted in elevated collagen deposition in mouse lungs and enhanced arginase activity [40], a feature of experimental lung fibrosis [41]. In this context, it is important to note that preterm infants requiring mechanical ventilation exhibited higher ADMA plasma levels than preterm infants who did not require mechanical ventilation [42]. As such, lung damage as evident in preterm infants under mechanical ventilation may lead to increased ADMA release via enhanced proteolysis and cell death. It is therefore reasonable to state that elevated serum/alveolar/pulmonary ADMA levels lead to vascular and/or interstitial remodeling in the lung, in the presence or absence of inflammation (Figure 2), but the causal relationship between lung injury, ADMA metabolism, and remodelling remains to be dissected in detail in future studies.

\section{Arginine methylation in COPD}

It has recently been suggested that NO metabolites, reactive oxygen species, and nitrosothiols represent novel targets for the prevention and treatment of chronic inflammatory airway diseases including asthma and chronic obstructive pulmonary disease (COPD) $[43,44]$. In contrast, little is known about methylarginine metabolism in the pathogenesis of these disorders. Since cigarette smoke represents the main risk factor for COPD, several studies have investigated the relationship between cigarette smoke and ADMA levels, with conflicting results. While some studies have found decreased ADMA levels in smokers compared with non-smokers $[45,46]$, others have detected increased ADMA levels in smokers, in the absence or presence of triple vessel coronary artery disease $[47,48]$.

A similar divergence is evident in in vitro studies using cigarette smoke extract (CSE)-treated cell cultures. The exposure of human endothelial cells to 10\% CSE decreased intracellular ADMA concentration via increased DDAH2 expression [46], while others have reported increased ADMA levels under such conditions [48]. In the absence of direct ADMA measurements in COPD or asthma patients, the available data therefore suggests that cigarette smoke is an important regulator of ADMA synthesis, but more conclusive in vivo and in vitro evidence is needed to assess whether COPD or asthma, or pathogenetic aspects thereof, are associated with altered ADMA levels.

\section{The relevance of plasma ADMA levels}

A significant debate about the contribution of plasma ADMA to the regulation of NOS-dependent NO produc- 


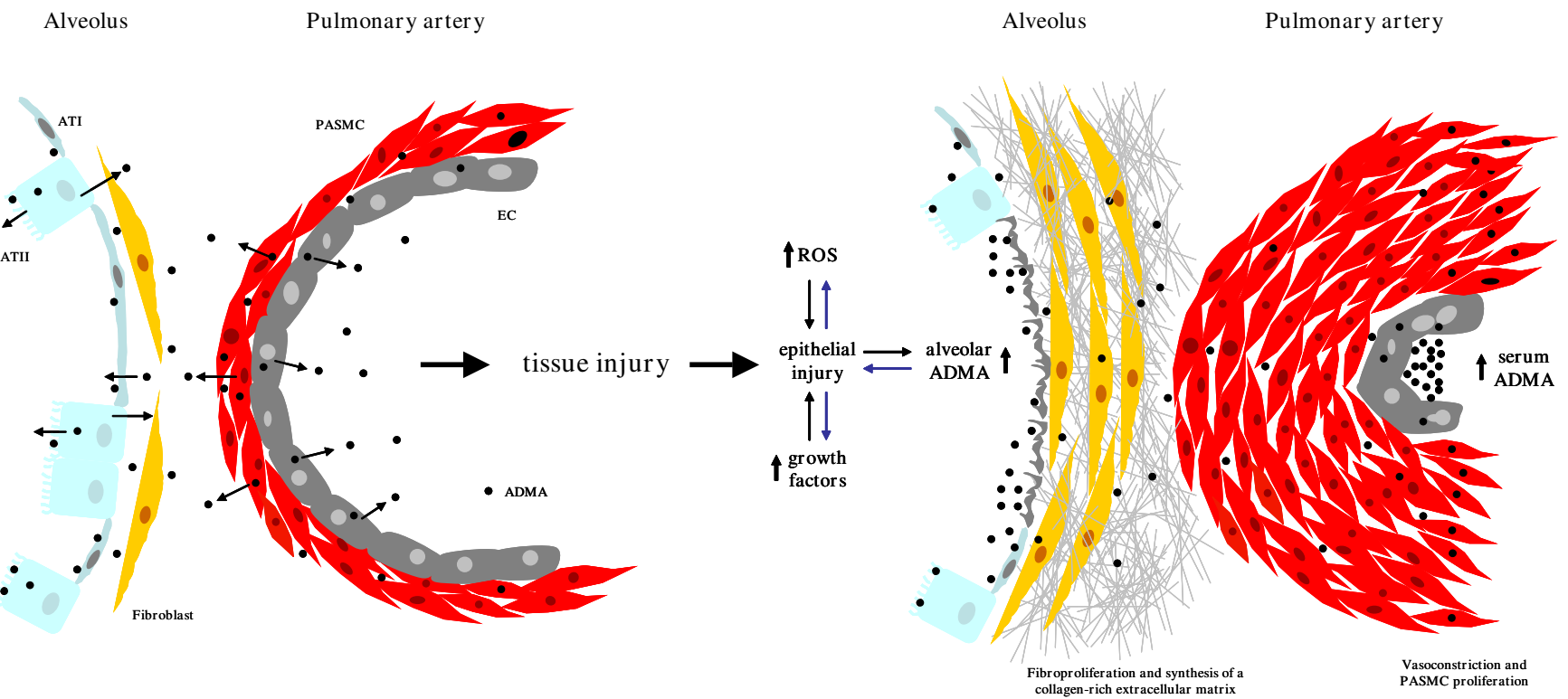

Figure 2

Abnormal protein arginine methylation triggers pathological changes in the lung. In the normal lung, methylarginines are generated via intracellular proteolysis and released to the intraalveolar, interstitial, and intravascular compartments of the lung. Pathological tissue injury, in particular alveolar epithelial cell injuries, leads to an increase of reactive oxygen species (ROS), growth factor production. This perpetuates epithelial cell damage and leads to increases of alveolar ADMA via increased proteolysis. Secondary pathological events of lung tissue injury include, but are not restricted to, fibroproliferation and deposition of extracellular matrix, as well as vasoconstriction and pulmonary artery smooth muscle cell (PASMC) proliferation. ATI; type I alveolar epithelial cell, ATII; type II alveolar epithelial cell type II, EC; endothelial cell.

tion has recently been initiated. In pathological conditions including $\mathrm{PH}$, plasma ADMA levels have been shown to increase to $0.53 \pm 0.15 \mu \mathrm{M}$ (from $0.36 \pm 0.05 \mu \mathrm{M}$ in controls) and $1.06 \pm 0.06 \mu \mathrm{M}$ (from $0.48 \pm 0.04 \mu \mathrm{M}$ ) in studies by Kielstein et al. and Pullamsetti et al. [22,23], respectively. Taking into consideration the physiological plasma levels of L-Arg of $100 \mu \mathrm{M}$, the normal plasma ADMA concentrations of $0.42 \pm 0.06 \mu \mathrm{M}$ [18] must approach approximately $10 \mu \mathrm{M}$ to elicit a significant effect on NO production and physiological functions thereof in the plasma [49]. It is therefore highly unlikely that plasma ADMA levels significantly contribute to decreased serum NO bioavailability observed in PAH or other cardiovascular disorders. In contrast, intracellular ADMA levels may significantly influence NOS activity under pathological conditions, as these have been shown to increase from 5.8 $\pm 1.2 \mu \mathrm{M}$ to $21.6 \pm 4.7 \mu \mathrm{M}$, for example, in carotid arteries subjected to balloon-induced vascular injury [49]. Increased intracellular ADMA levels may be particularly relevant to lung diseases, as the lung exhibits one of the highest baseline concentrations of intracellular ADMA [18]. Of note, small changes in plasma ADMA may serve as indicators of greater changes in intracellular ADMA. Therefore, further studies should closely investigate alterations of the intracellular methylarginine content in chronic lung disease, a factor that is clearly more likely to modify NO generation. In contrast, altered plasma ADMA levels may rather be a marker of disrupted methylarginine metabolism in selected intracellular compartments rather than a direct cause of structural or functional abnormalities in the cardiovascular system.

\section{Outlook}

In conclusion, dysregulated arginine methylation has now been shown to contribute to the pathogenesis of several pulmonary disorders, in experimental animal models as well as human disease. Causal relationships between dysregulated arginine methylation and the initiation, progression, or therapy of lung disease, however, remain to be dissected. Future investigations of arginine methylation dynamics in these diseases will therefore have to address, among others, the following questions:

1) Which tissues are the source of increased plasma ADMA levels in chronic lung disease?

2) Which specific cell types are the major contributors within a given tissue to altered plasma ADMA levels under pathophysiological conditions? 
3) Can dysregulated arginine methylation itself lead to altered lung structure and function?

Future studies will undoubtedly shed light on the relative importance of protein arginine methylation and highlight cellular events that are controlled by posttranslational modification of L-Arg residues under physiological and pathophysiological scenarios. The regulation of methylarginine metabolism by modulating cellular PRMT or DDAH activity will therefore likely present a novel therapeutic option for the treatment of chronic lung diseases such as PAH, IPF, asthma, or COPD.

\section{Statement of competing interests}

The authors declare that they have no competing interests.

\section{References}

I. Bedford MT, Richard S: Arginine methylation an emerging regulator of protein function. Mol Cell 2005, 18(3):263-272

2. Lee DY, Teyssier C, Strahl BD, Stallcup MR: Role of protein methylation in regulation of transcription. Endocr $\operatorname{Rev} 2005$, 26(2): 147- 170.

3. Vallance $P$, Leiper J: Cardiovascular biology of the asymmetric dimethylarginine:dimethylarginine dimethylaminohydrolase pathway. Arterioscler Thromb Vasc Biol 2004, 24(6): I023-1030.

4. Leiper JM, Vallance $P$ : The synthesis and metabolism of asymmetric dimethylarginine (ADMA). Eur J Clin Pharmacol 2006, 62(Suppl I3):33-38.

5. Closs El, Basha FZ, Habermeier A, Forstermann U: Interference of L-arginine analogues with L-arginine transport mediated by the y+ carrier hCAT-2B. Nitric Oxide 1997, I(I):65-73.

6. Ogawa T, Kimoto M, Sasaoka K: Dimethylarginine:pyruvate aminotransferase in rats. Purification, properties, and identity with alanine:glyoxylate aminotransferase 2. J Biol Chem 1990, 265(34):20938-20945.

7. Cuthbert GL, Daujat S, Snowden AW, Erdjument-Bromage H, Hagiwara T, Yamada M, Schneider R, Gregory PD, Tempst P, Bannister AJ et al: Histone deimination antagonizes arginine methylation. Cell 2004, I I 8(5):545-553.

8. Wang Y, Wysocka J, Sayegh J, Lee YH, Perlin JR, Leonelli L, Sonbuchner LS, McDonald CH, Cook RG, Dou Y, et al.: Human PAD4 regulates histone arginine methylation levels via demethylimination. Science 306(5694):279-283.

9. Raijmakers R, Zendman AJ, Egberts WV, Vossenaar ER, Raats J, Soede-Huijbregts C, Rutjes FP, van Veelen PA, Drijfhout JW, Pruijn GJ: Methylation of arginine residues interferes with citrullination by peptidylarginine deiminases in vitro. J Mol Biol 2007 367(4): III8-1 I 29.

10. Thompson PR, Fast W: Histone citrullination by protein arginine deiminase: is arginine methylation a green light or a roadblock? ACS Chem Biol 2006, I (7):433-44I.

11. Ogawa T, Kimoto M, Watanabe H, Sasaoka K: Metabolism of NG,NG-and NG,N'G-dimethylarginine in rats. Arch Biochem Biophys 1987, 252(2):526-537.

12. Teerlink T, Nijveldt RJ, de Jong S, van Leeuwen PA: Determination of arginine, asymmetric dimethylarginine, and symmetric dimethylarginine in human plasma and other biological samples by high-performance liquid chromatography. Anal Biochem 2002, 303(2): 131-137.

13. Boger RH: Asymmetric dimethylarginine (ADMA) and cardiovascular disease: insights from prospective clinical trials. Vasc Med 2005, I 0(Suppl I):S19-25.

14. Paik WK, Kim S: Protein methylase I. Purification and properties of the enzyme. J Biol Chem 1968, 243(9):2 I 08-2 I I4.

15. Vallance $\mathrm{P}$, Leone A, Calver A, Collier J, Moncada S: Accumulation of an endogenous inhibitor of nitric oxide synthesis in chronic renal failure. Lancet 1992, 339(8793):572-575

16. Dweik RA: The lung in the balance: arginine, methylated arginines, and nitric oxide. Am J Physiol Lung Cell Mol Physiol 2007, 292(I):LI5-I7.
17. Smith CL, Anthony S, Hubank M, Leiper JM, Vallance P: Effects of ADMA upon gene expression: an insight into the pathophysiological significance of raised plasma ADMA. PLOS Med 2005, 2(10):e264.

18. Bulau P, Zakrzewicz D, Kitowska K, Leiper J, Gunther A, Grimminger $\mathrm{F}$, Eickelberg $\mathrm{O}$ : Analysis of methylarginine metabolism in the cardiovascular system identifies the lung as a major source of ADMA. Am J Physiol Lung Cell Mol Physiol 2007, 292(I):LI8-24.

19. Ghofrani HA, Wilkins MW, Rich S: Uncertainties in the diagnosis and treatment of pulmonary arterial hypertension. Circulation 2008, II (1 I I): I1 $95-1201$

20. Humbert M, Morrell NW, Archer SL, Stenmark KR, MacLean MR, Lang IM, Christman BW, Weir EK, Eickelberg O, Voelkel NF, et al: Cellular and molecular pathobiology of pulmonary arterial hypertension. J Am Coll Cardiol 2004, 43 (I 2 SuppI S): I 3S-24S.

21. Gorenflo M, Zheng C, Werle E, Fiehn W, Ulmer HE: Plasma levels of asymmetrical dimethyl-L-arginine in patients with congenital heart disease and pulmonary hypertension. J Cardiovasc Pharmacol 200I, 37(4):489-492.

22. Pullamsetti $S$, Kiss L, Ghofrani HA, Voswinckel R, Haredza $P$ Klepetko W, Aigner C, Fink L, Muyal JP, Weissmann N, et al:: Increased levels and reduced catabolism of asymmetric and symmetric dimethylarginines in pulmonary hypertension. FASEB J 2005, 19(9): I I75-I I 77.

23. Kielstein JT, Bode-Boger SM, Hesse G, Martens-Lobenhoffer J, Takacs A, Fliser D, Hoeper MM: Asymmetrical dimethylarginine in idiopathic pulmonary arterial hypertension. Arterioscler Thromb Vasc Biol 2005, 25(7): |4|4-14|8.

24. Skoro-Sajer N, Mittermayer F, Panzenboeck A, Bonderman D, Sadushi R, Hitsch R, Jakowitsch J, Klepetko W, KneussI MP, Wolzt M, et al.: Asymmetric dimethylarginine is increased in chronic thromboembolic pulmonary hypertension. Am J Respir Crit Care Med 2007, I76(II): II54-II60.

25. Landburg PP, Teerlink T, van Beers EJ, Muskiet FA, Kappers-Klunne MC, van Esser JW, Mac Gillavry MR, Biemond BJ, Brandjes DP, Duits $\mathrm{AJ}$, et al.: Association of asymmetric dimethylarginine with sickle cell disease-related pulmonary hypertension. Haematologica 2008, 93(9): |4| $0-14 \mid 2$.

26. Dimitroulas T, Giannakoulas G, Sfetsios T, Karvounis H, Dimitroula $\mathrm{H}$, Koliakos G, Settas L: Asymmetrical dimethylarginine in systemic sclerosis-related pulmonary arterial hypertension. Rheumatology 2008, 47(I I): I682-1685

27. Xu W, Kaneko FT, Zheng S, Comhair SA, Janocha AJ, Goggans T, Thunnissen FB, Farver C, Hazen SL, Jennings C, et al.: Increased arginase II and decreased NO synthesis in endothelial cells of patients with pulmonary arterial hypertension. FASEB J 2004, 18(14): 1746-1748.

28. Sasaki A, Doi S, Mizutani S, Azuma $\mathrm{H}$ : Roles of accumulated endogenous nitric oxide synthase inhibitors, enhanced arginase activity, and attenuated nitric oxide synthase activity in endothelial cells for pulmonary hypertension in rats. $\mathrm{Am}$ Physiol Lung Cell Physiol 2007, 292(6):LI 480-LI 487.

29. Millatt LJ, Whitley GS, Li D, Leiper JM, Siragy HM, Carey RM, Johns RA: Evidence for dysregulation of dimethylarginine dimethylaminohydrolase I in chronic hypoxia-induced pulmonary hypertension. Circulation 2003, 108(I2):1493-1498.

30. Arrigoni FI, Vallance P, Haworth SG, Leiper JM: Metabolism of asymmetric dimethylarginines is regulated in the lung developmentally and with pulmonary hypertension induced by hypobaric hypoxia. Circulation 2003, I07(8): I 195-1201.

31. Yildirim AO, Bulau P, Zakrzewicz D, Kitowska KE, Weissmann N, Grimminger F, Morty RE, Eickelberg O: Increased protein arginine methylation in chronic hypoxia: role of protein arginine methyltransferases. Am J Respir Cell Mol Biol 2006, 35(4):436-443.

32. Dayoub H, Achan V, Adimoolam S, Jacobi J, Stuehlinger MC, Wang BY, Tsao PS, Kimoto M, Vallance P, Patterson AJ, et al:: Dimethylarginine dimethylaminohydrolase regulates nitric oxide synthesis: genetic and physiological evidence. Circulation 2003 I 08(24):3042-3047.

33. Leiper J, Nandi M, Torondel B, Murray-Rust J, Malaki M, O'Hara B, Rossiter S, Anthony S, Madhani M, Selwood D, et al: Disruption of methylarginine metabolism impairs vascular homeostasis. Nat Med 2007, 13(2): 1 98-203.

34. Hasegawa K, Wakino S, Tatematsu S, Yoshioka K, Homma K, Sugano $\mathrm{N}$, Kimoto M, Hayashi K, Itoh $\mathrm{H}$ : Role of asymmetric dimethyl- 
arginine in vascular injury in transgenic mice overexpressing dimethylarginie dimethylaminohydrolase 2. Circ Res 2007, I0I(2): $2-10$.

35. Martinez FJ, Safrin S, Weycker D, Starko KM, Bradford WZ, King TE Jr, Flaherty KR, Schwartz DA, Noble PW, Raghu G, et al.: The clinical course of patients with idiopathic pulmonary fibrosis. Ann Intern Med 2005, I 42(I 2 Pt I):963-967.

36. Selman M, Thannickal VJ, Pardo A, Zisman DA, Martinez FJ, Lynch JP 3rd: Idiopathic pulmonary fibrosis: pathogenesis and therapeutic approaches. Drugs 2004, 64(4):405-430.

37. $\mathrm{Li} X$, Rayford $\mathrm{H}$, Uhal $\mathrm{BD}$ : Essential roles for angiotensin receptor AT I $\mathrm{a}$ in bleomycin-induced apoptosis and lung fibrosis in mice. Am J Pathol 2003, 163(6):2523-2530.

38. Konigshoff M, Wilhelm A, Jahn A, Sedding D, Amarie OV, Eul B, Seeger W, Fink L, Gunther A, Eickelberg O, et al.: The angiotensin II receptor $\mathbf{2}$ is expressed and mediates angiotensin II signaling in lung fibrosis. Am J Respir Cell Mol Biol 2007, 37(6):640-650.

39. Jacobi J, Maas R, Cordasic N, Koch K, Schmieder RE, Boger RH, Hilgers KF: Role of asymmetric dimethylarginine for angiotensin II-induced target organ damage in mice. Am J Physiol Heart Circ Physiol 2008, 294(2): H I 058-1066.

40. Wells SM, Buford MC, Migliaccio CT, Holian A: Elevated Asymmetric Dimethylarginine Alters Lung Function and Induces Collagen Deposition in Mice. Am J Respir Cell Mol Biol 2008 in press.

41. Kitowska K, Zakrzewicz D, Konigshoff M, Chrobak I, Grimminger F, Seeger W, Bulau P, Eickelberg O: Functional role and speciesspecific contribution of arginases in pulmonary fibrosis. Am J Physiol Lung Cell Mol Physiol 2008, 294(I):L34-45.

42. Richir MC, van Leeuwen PA, Berg A van den, Wessels R, Twisk JW, Rauwerda JA, Teerlink T, de Vries TP, van Elburg RM: Plasma ADMA concentrations at birth and mechanical ventilation in preterm infants: a prospective pilot study. Ped Pulmonol 2008, 43(I2): || $6|-| \mid 66$.

43. Ricciardolo FL, Nijkamp FP, Folkerts G: Nitric oxide synthase (NOS) as therapeutic target for asthma and chronic obstructive pulmonary disease. Curr Drug Targets 2006, 7(6):72I-735.

44. Corradi M, Montuschi P, Donnelly LE, Pesci A, Kharitonov SA, Barnes $\mathrm{PJ}$ : Increased nitrosothiols in exhaled breath condensate in inflammatory airway diseases. Am J Respir Crit Care Med 200I, 163(4):854-858.

45. Eid HM, Arnesen H, Hjerkinn EM, Lyberg T, Seljeflot I: Relationship between obesity, smoking, and the endogenous nitric oxide synthase inhibitor, asymmetric dimethylarginine. Metabolism 2004, 53( I 2): 1574-1579.

46. Maas R, Schulze F, Baumert J, Lowel H, Hamraz K, Schwedhelm E, Koenig W, Boger RH: Asymmetric dimethylarginine, smoking, and risk of coronary heart disease in apparently healthy men: prospective analysis from the population-based Monitoring of Trends and Determinants in Cardiovascular Disease/Kooperative Gesundheitsforschung in der Region Augsburg study and experimental data. Clin Chem 2007, 53(4):693-70I.

47. Wang J, Sim AS, Wang XL, Salonikas C, Naidoo D, Wilcken DE: Relations between plasma asymmetric dimethylarginine (ADMA) and risk factors for coronary disease. Atherosclerosis 2006, 184(2):383-388.

48. Zhang WZ, Venardos K, Chin-Dusting J, Kaye DM: Adverse effects of cigarette smoke on NO bioavailability: role of arginine metabolism and oxidative stress. Hypertension 2006, 48(2):278-285.

49. Cardounel AJ, Cui H, Samouilov A, Johnson W, Kearns P, Tsai AL, Berka $V$, Zweier JL: Evidence for the pathophysiological role of endogenous methylarginines in regulation of endothelial NO production and vascular function. J Biol Chem 2007, 282(2):879-887.

\section{Pre-publication history}

The pre-publication history for this paper can be accessed here:

http://www.biomedcentral.com/1471-2466/9/5/prepub
Publish with Biomed Central and every scientist can read your work free of charge

"BioMed Central will be the most significant development for disseminating the results of biomedical research in our lifetime. "

Sir Paul Nurse, Cancer Research UK

Your research papers will be:

- available free of charge to the entire biomedical community

- peer reviewed and published immediately upon acceptance

- cited in PubMed and archived on PubMed Central

- yours - you keep the copyright

Submit your manuscript here:

http://www.biomedcentral.com/info/publishing_adv.asp
BioMedcentral 